\section{Ginzburg-Landau モデル}

相転移現象のミク ロな原因はさまざま であるが，その普遍的記述は Ginzburg-Landau モデル によってなされてきた。すなわち秩序变数と副次的に結合 する変数により, 現象論的な自由エネルギーを構築し相転 移現象を記述する。静的現象に関しては多くの体系が普遍 的なクラスに分けられるが，動的現象は体系の動的特性に よってさまざまなタイプのあのがある。外力や流動場のも とでは体系は大きく平衡からはずれうるが，このような非 平衡現象の研究にも, 本質的亡思われる要素のみを残した Ginzburg-Landau モデルが有効である。高分子系ではミ
クロな記述は複雑だが, 臨界現象研究で使われてきた Ginzburg-Landau 的考え方がたいへん役に立つ。この点 については de Gennes 氏の教科書を見られよ。この一見 複雑な現象への高度に抽象化したアプローチこそは, 数学 には疎くとも感覚鋭い実験家には有り難いものであり，野 心的理論家には新たな地平を拓く出発点となる。こんな現 象論的アプローチとは無縁だと思われている研究分野もあ るが (化学など), しかしこのような考えを導入するわず かの人間によりその分野のブレークスルーがあった例がい くつ屯ある。というわけで Landau 氏の影響は大である。

[254 頁]

\section{アトミスティックなMDシミュレーション}

低分子では数干原子程度の系で MD シミュレーションを 実行すれば，十分に凝集構造の物理化学的性質を反映する ことができる。この場合, それぞれの構成原子を最小単位 として, 各原子間に固有の分子内执よ゙分子間相互作用を 定義し，フェムト秒の時間刻みで運動させることは, 計算規模としてまったく問題がない。これがアト ミスティックな MD シミュレーションであり, 低分子の場合にはいちいち断る必要はな い。一方, 高分子で重要な力学的性質や粘 弾性は，秒以上の長時間の緩和過程に依存する。
これらの性質を再現するには，数千以上の原子からなる高 分子鎖が多数必要となり，無限の計算時間が必要になる。 そこで, 高分子の基本的な性質を壊さない程度に原子をグ ループ化し, 粗視化することが主流となっている。一方, 高分子中の水やガスなど, 低分子の拡散・透過を扱う場合 には，高分子鎖間の微妙な隙間が重要であり，原子レベル の精密さで高分子鎖構造を組み立てて運動を観測する ことが必要になる。高分子の場合，このような研 究をとくに「アトミスティックな MDシミュ

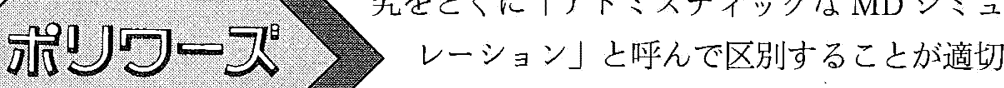
である。

[258 頁]

\section{モンテカルロ法}

モンテカルロ法は, 確率

（乱数）を使用するシミュレー ション法の総称である。モンテカルロは睹博で有名な町の 名前で, 確率論が博打の考察から生じたことを思い出せば 適切な命名であろう。この手法の応用は大きく 2 つある。 ひとつは物質の熱的性質を調べることで, 液体, ガラス, 複雑液体などのシミュレーション法としては分子動力学法 と双璧をなしている。モンテカルロ法では, 分子動力学法 のようにニュートン運動方程式を解くことはせず，ある状 態加ら次の状態を乱数で発生させる。次々と生成した状態
からなる統計集団がボルッマン分布になるメトロポリス 法は有名で，相転移現象の解明には有効性を発揮してきた。 高分子を例にとれば，モノマーをランダムに微小距離（低 温では高エネルギー状態に低確率, 低エネルギー状態に高 確率で）移動させる。多数の試行の結果として物理的に期 待される状態に落ち着くのである。あうひとつの応用は, 確率過程を含むような体系への応用である。この方面では ブラウン運動, 浸透など物質科学に限らず, 伝染病伝播, 交通流, 生態系, 株式相場など複雑系への応用が広がって いる。

[263 頁 ]

\section{ショャイロイド構造}

ジャイロイド構造は, 周期 的極小曲面をむつ立方構造の ひとつで, Ia $\overline{3} \mathrm{~d}$ の空間対称性をもつ。 $\mathrm{AB}$ 二元ブロック 共重合体で $\mathrm{A}$ 鎖が B 鎖より短い場合を考えると, Bのマ トリックス中における A の柱状ドメインが 2 つの連結 ネットワークをつくる。そのため，このジャイロイド構造 はダブルジャイロイドと呼ばれることがある。2つのネッ トワークは左巻きと右巻きになっており，互いが交わらな いように織り合わさっている。それぞれのネットワークの 接合部では 3 本のドメインに分かれている。B 鎖が短い
場合はこの逆で, Aのドメインがマトリックスに, Bのド メインがネットワークになる。 80 年代半ば, 共重合体の 電子顕微鏡観察からラメラ相とへキサゴナルシリンダー相 の間に，それまで知られていなかった構造があると報告さ れた。この構造がジャイロイド構造であることは 90 年代 になってはっきりした。水・界面活性剤系では 1960 年頃 からジャイロイド構造が見つかっていた。この説明は www.msri.org/publications/sgp/SGP/を一部分参考に した。

[267 頁] 